\title{
Varieties of capitalism, growth and redistribution in Asia and Latin America
}

\author{
Variedades de capitalismo, crescimento $e$ \\ redistribuição na Ásia e na América Latina
}

ILAN BIZBERG*, **

\begin{abstract}
RESUMO: Tanto a América Latina quanto a Ásia observaram um crescimento impressionante de suas economias desde a virada do século até 2013. Uma das diferenças é que, enquanto na América Latina a redistribuição e a segurança social aumentaram significativamente e o crescimento foi acompanhado por uma menor desigualdade, na Ásia vimos o aumento da desigualdade, uma proteção social mais ineficiente e decrescente e sem intenção de redistribuir. Este artigo procura demonstrar de que modo o desenvolvimento da Ásia, caracterizado principalmente pela China, é mais sustentável do que o modelo seguido pela América Latina.
\end{abstract}

PALAVRAS-CHAVE: Diversidade de capitalismos; América Latina; Ásia, redistribuição; sustentabilidade.

ABSTRACT: Both Latin America and Asia observed an impressive growth of their economies from the turn of the century until 2013. One of the differences between Asia and Latin America is that while redistribution and social security increased significantly in the second and growth was accompanied by reduced inequality, in Asia we have seen the contrary, increasing inequality, a more inefficient and decreasing social protection and no intent to redistribute. This paper wants to answer in what respects the mode of development of Asia, as characterized mainly by China, is more sustainable than the one followed by Latin America.

KEYWORDS: Diversity of capitalisms; Latin America; Asia; redistribution; sustainability. JEL Classification: P5.

\footnotetext{
* Centro de Estudios Internacionales, El Colegio del Mexico - COLMEX, Mexico. E-mail: ilan@ colmex.mx.

"."Associate member CADIS/EHESS, France. Submitted: 21/March/2017; Approved: 12/ May/2017.
} 
Both Latin America and Asia observed an impressive growth of their economies from the turn of the century until 2013. in Latin America, growth was, for the first time since ISI (1940's to end of the 1970's), accompanied by a diminution of the great inequality that has characterized this continent due to both a decisive effort of redistribution and the effects of economic growth. In fact, one of the characteristics of the mode of development adopted by many Latin American countries during the commodity super cycle (especially Brazil and Argentina) was to redistribute in order to expand the internal market, allow for the growth of the middle classes and impulse economic growth; a wage led growth (Boyer, 2014). In the midst of the present economic and (notably in Brazil) also political crisis, the question of the sustainability of the growth mode followed by these countries is forcibly posed, and the stability of the gains in terms of reduced inequality and poverty and the growth of the middle classes is also raised.

The growth of Asia was equally very significant in this period; in fact, the main factor of growth in Latin America depended on the expansion of the economies of China and other countries of Asia. The extensive growth of China (coupled with the financial expansion of the United States economy) impelled growth in Latin America (Boyer 2014), and the present deceleration of this country's economy has led to the present crisis in many of the countries of the continent that depended on the Asian giant. The growth of East Asia has led to the creation of jobs, the increase of productivity, salaries and the expansion of the middle classes. Nonetheless, one of the differences between Asia and Latin America is that while redistribution and social security increased significantly in the second and growth was accompanied by reduced inequality (in a much more unequal continent), in Asia we have seen the contrary, increasing inequality, a more inefficient and decreasing social protection and no intent to redistribute.

Our main question in this paper will be to answer in what respects the mode of development of Asia, as characterized mainly by China, is more sustainable than the one followed by Latin America. Is the unsustainability of this growth in the case of Latin America related to redistribution, or rather to insufficient or faulty industrial policies due to (or leading to) a dependence on the export of commodities, or rather the lack of synchronization of both (which is the hypothesis of this article)? Is sustainability, in the case of Asia (more specifically China), related to an emphasis on higher investment rates, higher productivity growth, more efficient industrial policies, rather than redistribution? In the case of Latin America, is a wage led growth strategy (such as the one followed by Brazil and Argentina) less efficient in assuring sustainability than an export led growth (such as the one followed by Mexico and Chile)?

In order to try to answer these queries I will divide this paper in three parts and a conclusion:

First, I will describe the situation regarding growth, investment, productivity, salaries and social security expenditure and the dynamics of inequality in Latin America and Asia. 
Second, I will then shift the focus from a discussion on poverty reduction and decrease of inequality to that of the growth of the middle class in both continents.

Third, I will then analyze the case of Brazil and China as the ideal types of two distinct modes of development symbolizing the Latin American growth regime and the Asian one. I will then ask if the Mexican case is the equivalent of the Chinese model for Latin America.

Fourth, I will end this article with a conclusion on the strengths and weaknesses of these three types of capitalism.

\section{GROWTH, INVESTMENT, AND THE DYNAMICS OF INEQUALITY IN LATIN AMERICA AND ASIA}

When one compares the performance of Latin America and Asia in the last 15 years one can, in the first place, notice that in both continents there has been a very significant growth. Latin America has grown at a much more considerable rate that in the nineties, not to mention the lost decade of the 80s. Nonetheless, while the growth of Latin American economies has been very impressive with regards to their own past, it has paled with respect to Asia, especially to China (Figure 1).

Figure 1: GDP growth (annual \%)

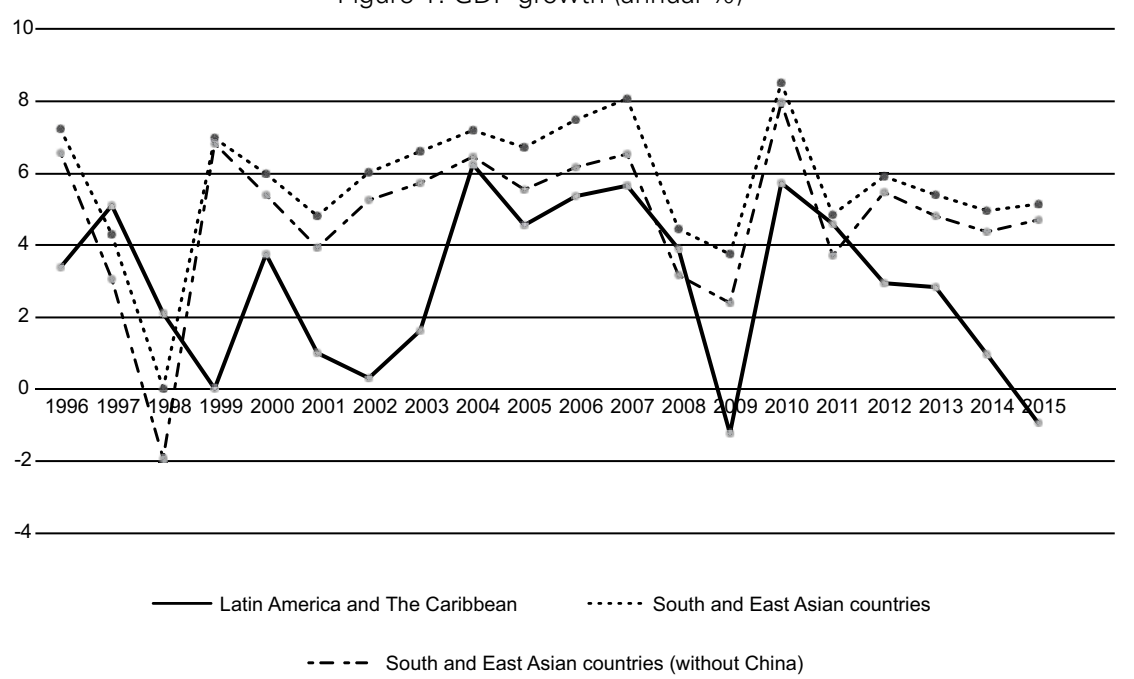

This growth is the result of significant investments, more intense in Asia than in Latin America. While in this latter, gross capital formation is around 20\% yearly, in China the average is around $40 \%$ of GDP, as was the case in Korea and Taiwan in the $60 \mathrm{~s}$ and seventies. In this manner, one of the most significant differences between both continents is the rate of investment, more than double in Asia as compared to Latin America (Figure 2). Another very important difference be- 
tween both continents is that while in most of Latin America (except Mexico) this growth led to a diminution of inequality, in Asia the contrary happened, inequality, albeit still much lower than in Latin America, has stayed almost constant or has increased (most notably in China) (Figure 3).

Figure 2: Gross Capital Formation (\% of GDP)

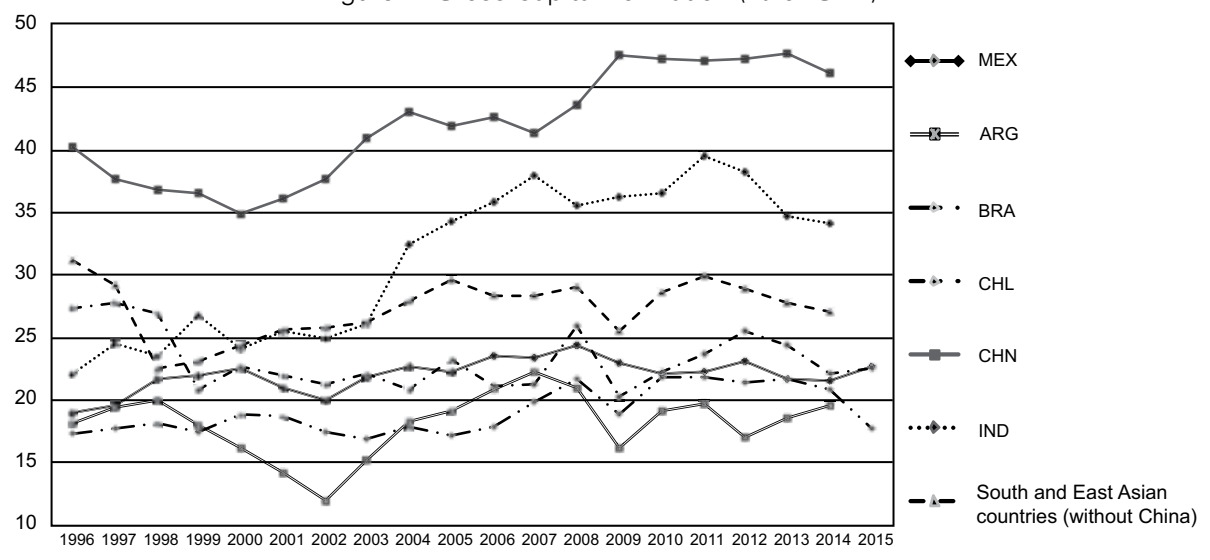

Note: South and East Asian Countries include China, India, Philippines and Thailand.

Source: World Bank, Databank.

Figure 3: Gini Index

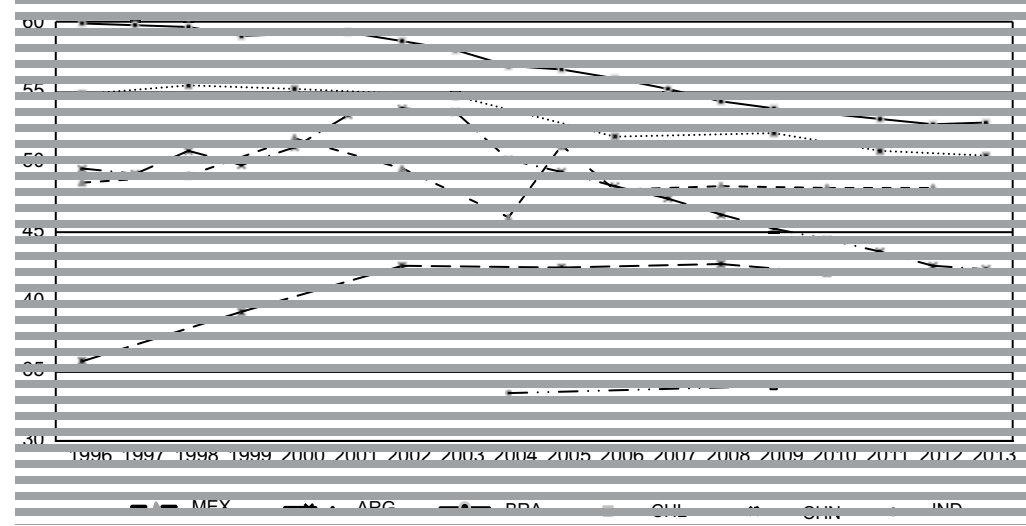

Source: World Bank, Databank.

Another important difference between both continents is fiscal pressure. It is higher in Latin America than in Asia, something that has allowed for an effort of redistribution though social services, as exemplified with public health expenditure (Figure 4) and explains, in part, the diminution of inequality in the former. In general, Asian emergent countries, have not devoted their public resources to social protection as have the countries in Latin America. 
Figure 4: Health expenditure, public (\% of GDP)

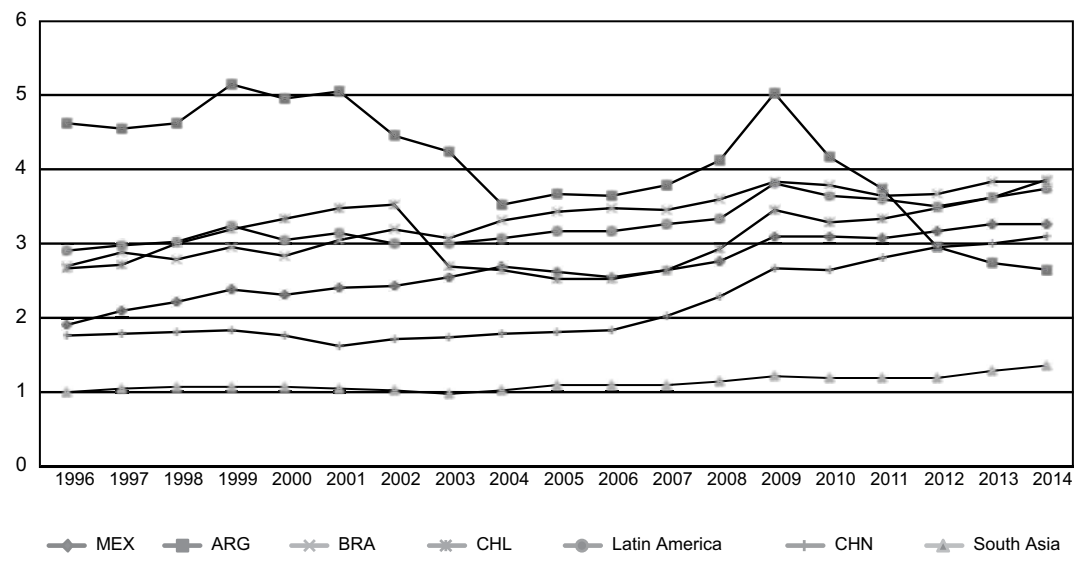

We have seen how wages (especially real minimum wages) have been growing very rapidly in most countries of Latin America (except Mexico); especially in Brazil and Argentina (Bizberg, 2011 and 2014), most probably at a faster rate than productivity. In China, we have seen the contrary process, productivity has grown much faster than salaries, through, for one-part, migration from very low productivity sectors in agriculture to high productivity in urban and industrial sectors (Boyer, 2012). A hike in productivity that has grown much faster than salaries (like Korea and Taiwan in the past) which have been limited through the control of the official unions; although more recently there have been some significant hikes in some industries after wild/ unofficial strikes.

In more general terms, while Latin America has dedicated a significant part of the resources it accumulated during the commodities boom to redistribute through salary hikes (especially minimum salaries), the extension of the pension system, assistance programs, health and education, the Asian countries have dedicated their resources basically to reinvestment in the State-owned enterprises and in physical infrastructure (Kharas, 2010; Boyer, 2012). One of the clearest indicators of this difference in both cases is exemplified by the comparison between the composition of GDP between China and Brazil (Figure 5). We can see that while general government is quite larger in Brazil than in China, gross capital formation is much larger in this latter country than in Brazil, and final consumption expenditure is much higher in Brazil. This may lead us to characterize, in general, the growth model followed by some of the Latin American countries (although we will later on make a difference between Brazil and Mexico), as a wage led growth, while that of China may be characterized as an investment led growth. 


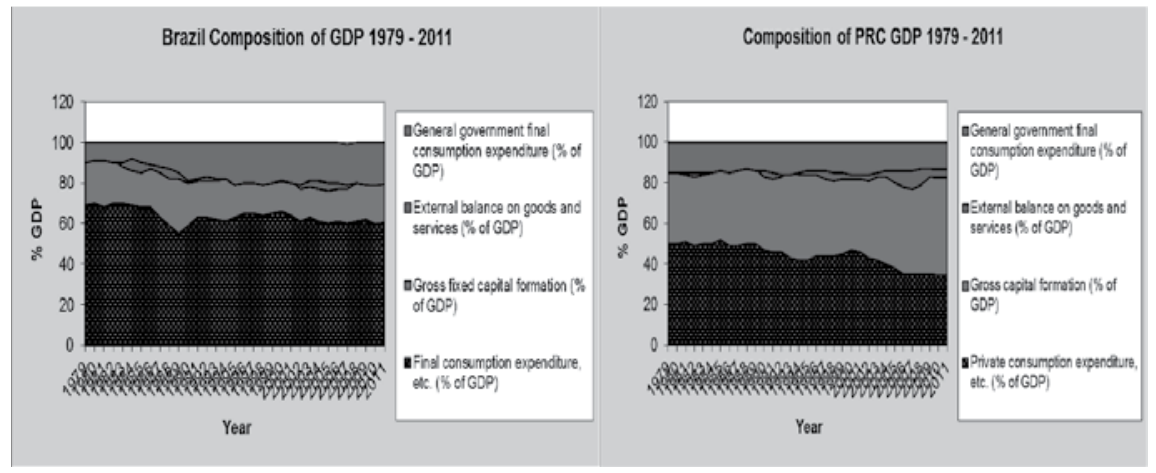

Source: Frank Hawke, "The Post-Liberation Economy and the Development of International Imbalances (Basics + Pre-reform Period)," PowerPoint, Peking University.

\section{FROM A FOCUS ON THE REDUCTION OF POVERTY AND INEQUALITY TO THAT OF THE GROWTH OF THE MIDDLE CLASSES}

While in the case of Latin America what has been emphasized in the last years before the present crisis is the reduction of poverty and the decline of inequality, the focus in Asia has been the growth of the middle classes. In fact, many of the analysts writing on Asia consider that governments should concentrate on the growth of the middle class even if this implies more inequality; supposedly preventing inequality that benefits the rich (Kharas, 2010, p. 31). The analysts that have studied the Latin American experience consider, on the contrary, that the focus should be to reduce inequality, to increase the revenues of the poorest and the vulnerable, rather than those of the middle class (Salama, 2014, p. 11).

Middle classes are considered to be central for economic growth, be it through consumer capacity, entrepreneurship and/or democratic stability. The first author to write about the importance of the middle classes was Aristotle. In his On Politics, he defended the idea that the middle classes are crucial to assure the stability of a political system because they are conservative: they do not want radical changes because they have too much to lose. The modernization theory said more or less the same thing with regards to democracy, when it proposed that democracy follows the growth of the middle classes. More recently, Birdsall writes that middle classes are crucial for sustainable growth "[...] to the extent that the problems of rent-seeking and corruption associated with highly concentrated gains are avoided; and politically to the extent that conflict and horizontal inequalities between racial and ethnic groups are easier to manage (Birdsall, 2010, cited by Asian Development Bank, 2014, p. 2). In addition, Alesina poses that a society that is lacking a large middle class, a society divided between the poor and the rich, implies more polarization, is dominated by a distributive conflict and, in consequence, is less capable of reaching decisions that are conducive to economic development (Alesina, 1994, 
cited by Asian Development Bank, 2014). This situation induces less investment in physical infrastructure, education, health, and other public goods, all of them essential for economic growth (Easterly, cited by ADB, 2014).

More directly related to economic growth, a reorientation from an export oriented economy to an internal oriented economy depends on the internal market, which in its turn depends on a larger middle class (Asian Development Bank, 2014, p. 1). Middle class demand is crucial for economic growth, not only because this sector has more resources to spend in non-basic goods, but in that they tend to desire higher quality and more complex goods that require a more complex productive structure which, if developed internally, may induce development (Ibid.). Additionally, Banerjee and Duflo (2008, cited by Asian Development Bank, 2014), consider that a larger middle class includes individuals that have enough resources from savings that they may be incited to invest in productive activities and become entrepreneurs. These authors also consider that fact that the middle classes are more focused on human capital also favor economic development.

All of this implies that the existence of a large middle class makes economic growth more sustainable. Something that is crucial to all developing countries, especially the Latin America ones, that have gone thorough waves of growth and deceleration. Rodrik has consistently posed that while spurts of growth are rather easy to achieve, but constitute a sort of Sisyphus stone that many countries have encountered in the past, sustainable growth requires structural and institutional conditions that allow a country to endure external shocks (Rodrik, 2007).

The authors that focus their interest on Asia, also connect the growth of the middle classes with the possibility of escaping the middle-income trap, which is determined by rising costs and declining competitiveness of the economy of the countries that have reached a certain level of income (Ozturk, 2016, p. 726). They consider that the growth of the middle classes is crucial not only to hasten economic growth, but also to transit from a low to a high-income economy and avoid the middle-income trap (Ibid.: 727). According to Ozturk, “[...] as a country grows from low to higher income categories, it gets harder to grow further because of the diminishing marginal effects of the growth factors [...] the middle class income share is very effective in escaping the middle-income trap" (Ibid. , p. 727). In fact, according to this author, most countries of Latin America, have been stuck in this middle-income trap for the last 20 years.

In contrast, an author looking at Asia from the Latin American perspective considers that rather than middle classes assuring growth, it is the contrary that is the case: growth is the cause of the emergence of the middle classes. He also writes that in the case of China, it is not the consumption of the middle classes that explains growth, as private consumption is rather, but it's investment and the increase of exports that explains growth (Salama, 2014, p. 10).

Most authors agree that during the last 15 years the middle classes in Latin America and Asia have grown considerably, and that they will most certainly become a significant part of the global middle class (Milanovic and Yitzhaki, 2002 and Kandogan and Johnson, 2016). For Latin America, both the IDB and the UNDP restrict the definition of the middle class by inserting, between them and the poor, 
the category of the vulnerable, which in fact has been the sector that has grown most during these last years in this continent. In this manner, the poor are those living under 2 dollars a day, the vulnerable those between 2 and 10 dollars, the middle classe those between 10 and 50 dollars, and the rich (called residual) those above 50 dollars. It significant that in some countries what has grown most is the vulnerable sector (Bolivia and Colombia), while in others it has been, in effect, the middle classes (Argentina, Chile, Brazil and Uruguay), while in others still (basically Mexico) the middle classes and the vulnerable sector have grown less in the last decade, the class structure of this country having been thus established before, most probably during the nineties (Figure 6).

Figure 6: Gini Index

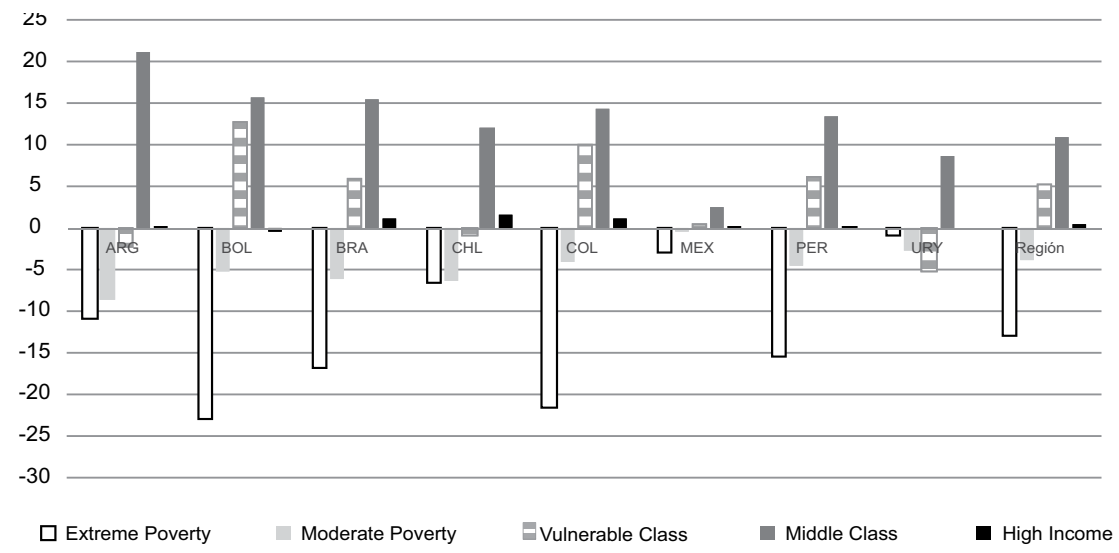

Source: Marco Stampini, Marcos Robre, Mayra Sáenz, Pablo Ibarrarán, Nadin Medellín, “Pobreza, vulnerabilidad y la clase media en América Latina", Documento de trabajo del BID no. 591, IDB, May 2015

In Brazil, one of the countries that appeared to have been developing most successfully until the present crisis, since the mid 2000 the economic policy emphasis began shifting towards the increase of the middle class, of a new middle class (class C), that had left poverty behind (it was thought permanently), had a stable job (with Carteira de trabalho), had access to social security, health services, began buying durable consumer goods, and started to have access to credit and housing amounted to $50.5 \%$ \% of the population in 2009 (Cortes Neri, 2008, p. 39 and 2011, p. 91).

In the case of China, Kharas (2010, pp. 30-32) considers its middle class to be around $12 \%$ of the population (157 millions in 2010). Based on qualitative characteristics, centered on occupation, considering mainly individuals linked to State and communal enterprises, Chen calculates the Chinese middle class to be around $24.4 \%$ of the urban population (Chen, 2013, p. 36).

Nonetheless, the policies leading to middle class's growth are different in both continents. While in Brazil middle classes have grown due to redistribution and employment formalization, in a word through the expansion of consumption, both private and State, in China, consumption has lagged behind investment. In fact, in 
this latter country, "whereas the number of wage earners has drastically increased with the shift from rural to urban labor, the share of household consumption in total demand has declined" (Boyer, 2012, p. 196). The "[...] wage share in GDP has fallen from two-thirds in 1980 too just over half of GDP today." Thus, household final consumption accounts for only $37 \%$ of total output, much lower than in most Asian countries and in Latin America (Kharas, 2010, p. 32). Paradoxically, the increase of the middle classes is accompanied by a tendency of decreasing mean revenue, and also by the fact that the mean revenue of the middle classes grows less than that of the rich but more rapidly than that of the poor (Salama, 2014). In contrast, according to Scalon and Salata (2012, p. 404), the process that Brazil underwent between 2002 and 2009, in terms of the expansion of the labor market and income growth, favored the lower classes, creating a new middle class (and a vulnerable sector); something that was also the case in the other countries in Latin America where the governments had active policies of redistribution.

\section{THREE DISTINCT CAPITALISTIC MODES: BRAZIL, CHINA, AND MEXICO}

The mode of development a country pursues does not depend exclusively on the decision of the government, on a pure economic policy decision, but it hinges on the distinct social covenant that has been established. Cardoso and Faletto stressed that one of the most significant socio-political differences between the central/developed countries and the Latin American ones was that while the advanced economies set forth their industrialization in a situation where most of the population was still rural and the transition from rurality to urbanization lasted decades or even centuries, Latin American countries were already relatively urbanized when they began to industrialize. On the other hand, while in the central countries unionism was inexistent, and in general the organization and the capacity of exerting pressure on the part of the popular classes was minimal, or almost inexistent, in Latin American, both urbanization and the existence of unionism in some economic sectors (mining, oil extraction, meat packing, railroads), constituted a significant pressure factor, together with political parties representing the middle classes and in some cases the workers. Urbanization meant that the population had consumer habits such as the ones existing in the central countries, social and political organization meant that part of the population could in fact exert pressure to attain their demands (Cardoso and Faletto, 1969).

In contrast, agrarian reform in the case of Korea and Taiwan, anchored a significant part of the population at the countryside (Haggard, 1990). In China, the hukou system makes it difficult to migrate from the countryside to the cities or within provinces without a permit. In addition, the Korea and Taiwan industrialized under a dictatorship that excluded unions or political parties. In present day authoritarian China, the situation is very similar as unions are controlled by the State and there is a single/hegemonic party: the Chinese Communist Party. In contrast, Brazil in the eighties and Argentina in the years 2000, saw the emergence of 
strong social movements and organizations, which imposed themselves and forced their incorporation into a social pact. This meant that the governments of both countries (in the years 2000, under parties linked to labor) were forced to redistribution.

While in the economic mode followed by some Latin America in the last decade, the State established compromise between the financial and commodities exporters on one side and the popular sectors, the poor and the vulnerable, on the other (most notably in Brazil and Bolivia), in China, the State has established a state-corporatist pact with the population and a local-corporatist pact between the local governments (villages, cities, provinces) and national and international private investors (Boyer, 2012). In Latin America, the social compromise has meant that the State has increased redistribution of profits to the poor through minimum salary hikes and investment in social security and services, while simultaneously favoring financial capital with high interest rates (especially of government bonds), free movement of capitals, and high exchange rate; positions that showed themselves to be antinomic and eventually untenable, leading to the present crisis (Bruno and Marques-Pereira, 2015). In China, the population accepts the authoritarian regime, bad working conditions, low salaries, lack of social services in exchange for fast economic growth and hope of a better future for them or their children, while national and international capitals accept an alliance with the State, uncertain property rights and a weak rule of the State for present and future investment opportunities; both positions that reinforce each other (Boyer, 2012).

During the years when the socio-developmentist model was implemented (Bresser-Pereira, 2015; Prates, Fritz and De Paula, 2017), the Brazilian government was ruled by the Workers Party, originally linked to the main Brazilian trade union, the CUT, an offspring of the resurgence of the civil society during the last years of the dictatorship, that led to a very significant and heterogeneous civil society movement that eventually displaced the military, forced elections and the writing of a new Constitution (in 1988) which gave significant social rights to the Brazilian population. Due to its origins, the PT government was forced to implement an ample (although Brazilians further to the left criticize its limitations) social redistribution program through significant increases of the minimum salaries (that almost doubled in 10 years), the expansion of the universal health system (SUS, founded in 1990), the extension of the assistance program Bolsa Familia, the increase of non-contributory pensions and, the creation of a popular housing construction and loan program Minha casa minha vida. The social and infrastructure expenditures of the Brazilian State (already very high by Latin American standards) increased considerably, hiking the need for financial resources on the part of the State and causing the rise of the interest rates, nurturing the process of financialization. A situation, which in political economic terms, reflected a(n) (unstable, and eventually untenable) compromise of the PT government with the popular classes, and with the financial and commodities export capitals (Bruno and Marques-Pereira, 2015).

The logic of redistribution was not exclusively attributable to the social pact 
between the State and civil society, especially the poor and the popular classes, but also followed an economic rationale. A continental country, with an enormous population, had the possibility (and the need) that its economy depends on the internal market, this was the basis of the Import Substitution Industrialization of the "golden Thirties", and what the wage led growth, or neo-structuralist or socio-structuralist mode implemented by the PT governments demanded (Bresser-Pereira, 2015; Prates, Fritz and De Paula, 2017). Redistribution, credit, State investment in infrastructure, and policy support of specific economic sectors were crucial to reorient part of the profits generated by the export of commodities in order to develop the country on the basis of the internal market. The efforts to increase the buying power of the popular classes, reduce poverty and expand the middle class, were central (Bizberg, 2011 and 2014).

In this manner, the decline of poverty and the expansion of the middle classes was a consequence of a growth model based on the internal market, redistribution, the increase of fiscal pressure and contributions collected by the State. The significant increase in salaries, especially minimum salaries, as well as a process of formalization of the working force contributed to this aim. In addition, there was an intensive program of housing for the poor, financed wholly or partly by the State, and an increased access to credit by the popular sectors; which allowed them to acquire durable consumer products. All these factors resulted in a significant growth of the internal demand, which was at the center of the socio-developmentist model, that was assumed to achieve (with the guidance of active industrial policies) the deepening of industrialization. Nonetheless, national production did not follow. Mainly because it was accompanied by an overvaluation of the national currency due to the entry of foreign currency resulting from the increased exports of commodities and foreign investments (the "Dutch disease"), which resulted in an increase of imports and de-industrialization (Bresser-Pereira, 2012 and 2015). The premature expansion of the internal demand, before the productive structure was ready to meet the demand, that resulted in a much faster growth of the internal demand than that the internal offer, and a multiplier effect benefiting the external market (Salama, 2012), together with an overvalued real, ensued in de-industrialization (Bresser-Pereira, 2012 and 2015; Aguila and Lo Vuolo, 2016; Salama, 2012). The compromise with the financial and commodity exporting interests that eventually led to the "Dutch disease" made internal production costlier and imports cheaper and defeated all of the industrial policies (favouring the middle and small enterprises) that the government had undertaken (Bresser-Pereira, 2012 and 2015). De-industrialization resulted from an increased export of commodities, the influx of foreign exchange, both as a result of these exports, as well as in the form of foreign capital in different activities, especially in State bonds. This influx of foreign exchange increased the exchange rate in favor of the real, while the increase of spending by the Brazilian government maintained the interest rate at very high levels; both resulted in the fact that investment in governmental bonds very lucrative for both foreigners and nationals. This situation had as its consequence a rise in favor of rentier investments, in government bonds and commodities, instead of 
more productive ones in industry or knowledge technology (Bresser-Pereira, 2012 and 2015; Bruno and Marques Pereira, 2015; Salama, 2012). All of which, eventually contributed to the demise of the socio-developmentist model.

In addition, this model of development was very dependent on the financial expansion and low interest policies of the United States, together with the spectacular growth of China, that raised both the demand and the price of commodities. Once these two conditions deteriorated, first the credit crush due to the global crisis, that led to the retreat of foreign capital from the emerging countries and the reduction of foreign investment, then the hiking of interest rates in the United States, and finally the deceleration of the Chinese economy, reduced the resources available, the Brazilian compromise crashed (Boyer, 2014). A situation that, in part led, and in part was deepened by the political crisis. A mix of orthodox and heterodox policies (Prates, Fritz and De Paula, 2017) alienated the social bases of the PT and the agro-exporting and financial sector, and weakened the position of the second of Dilma's government. Once the heads of the PMDB, that formed the political coalition that supported her presidency began to be threatened by the Lava Jato corruption investigation, they broke up the coalition and eventually wrought a maneuver to force her ousting and replacement by her PMDB vice-president, Michael Temer. This maneuver deepened both the political and economic crises, which seem to have no end.

In China, economic growth, the reduction of poverty and the expansion of the middle class, has been basically the consequence of investment in manufacturing and infrastructure, that gave rise to a significant expansion of State, collective and private owned enterprises that have consolidated this country as the main manufacturer of the world. The economic expansion oriented towards the external market has been achieved through important productivity increases, due to migration from low productivity activities (from the countryside), investment in technology and $\mathrm{R} \& \mathrm{D}$, low salaries and the undervaluation of the national currency. These factors have not only allowed for the impressive increase in exports, but also the massive reinvestment of profits by the State (local and national) and the private entrepreneurs (Boyer, n.d. and 2014).

This mode of capitalism seems to assure a more stable and sustainable growth pattern. This country-continent, that has historically been under strong centrifugal forces, has always required powerful and centralized governments and has, since the death of Mao in 1979, launched a vast effort to achieve economic development as one of the means to maintain its unity. Economic growth is the contemporary manner in which the communist party has found to perpetuate its power and maintain the unity of the country. In order to preserve stability and political control, it must align the interests of the bureaucrats and the other members of the communist party (around 90 million) upon a common aim, while providing the population with economic benefits and better living conditions. The way to achieve these goals is to develop the country; thus, economic growth is not an end, but an instrument, a political one (Aglietta and Bai, 2012, pp. 17 and 120-2).

The Chinese economic model is based on two compromises: a socio-economic 
compromise between the communist party and the population, founded on the acceptance on the part of the Chinese population of political submission in exchange of economic growth ${ }^{1}$ (Boyer, 2012). This is a fact for the people that have come out of poverty through economic growth and the middle classes that depend so strongly on the State for their employment (Chen, 2013). The second compromise is between the political elites and the economic ones, based on the cooperation between both of them to assure economic growth (Boyer, 2012). These two converging compromises contrast with the socio-economic agreement in Brazil, that was established between two socio-economic sectors with diverging interests: the financial capital and the commodity exporters, on the one hand, and the popular sectors and new middle classes dependent on the internal market, on the other.

China's model of development is based on the accelerated growth of manufactured products that are exported to the rest of the world. Although this country began exporting low aggregate value products it has been upgrading its production continuously. This has been possible because the authoritarian Chinese State has a strategic outlook and the capacity to modify its route when it finds obstacles or failures through the political control of the communist party. Government authorities have taken advantage of the sheer size of the Chinese market and the impressive growth of the last decades to impose rules upon private capitals that desire to invest in the country, such as co-investment with public capitals, the integration of local suppliers and transfer of technology.

In fact, the mode of development implemented in China is a hybrid among state, private and foreign capital, embedded at the local level. A model that Boyer calls a local-state-corporatism. Because the local governments have the capacity of defining the rights of the use of the resources, they use this leverage to develop their region in order to assure more resources and the preservation of political control. This has given rise to a very competitive economic model, where towns, districts and provinces compete fiercely to attract private investment. On the other hand, each local public entity is partially accountable to another entity of higher rank, that can correct the performance of a public/private company or a local government. In this way, local governments and entrepreneurs are regulated by a fierce economic competition and by a national State that monitors the performance of the local authorities in order to assure the preservation of its political control. This is possible by the authoritarian control exerted by the central government through the monopoly of the communist party (Boyer, n.d.).

Mexican capitalism is also an export led economy, equally based on the manufacturing sector and exports, that has maintained macroeconomic stability; it has not stumbled upon an open crisis since 1995 and recovered very rapidly from

\footnotetext{
${ }^{1}$ A situation that is reminiscent of what happened in most Latin American countries, and especially in the case of Mexico, where a revolutionary party took over and pushed for economic growth in order to legitimize itself and in Brazil, where the military that took over in 1964, invested heavily in capital and intermediary industry to deepen industrialization and maintain economic growth.
} 
the 2008 global crisis. It may be (and has been) considered as a sustainable model. Nonetheless, it has significant structural problems. In the first place, in contrast with China, it is a low investment, low growth, low job creation mode. It is also stuck in a low (or null) upgrading trap, radically different from the upgrading process the Chinese economy is undergoing. For all these reasons, one could define its situation as a low intensity, permanent, or rampant crisis.

It is an export oriented model, profoundly dependent on foreign investment. The Mexican economy is basically (but not completely) a platform for maquiladoras, that merely assemble spare parts that are imported, and other industries that integrate a larger proportion of spare parts produced internally, mainly by foreign subsidiaries or suppliers of these same companies. We have formalized/stylized this type of capitalism as an International outsourcing capitalism (Bizberg, 2014). It is a disarticulated form of capitalism that depends entirely on the demand of parent companies that are situated in the United States or other central countries, that imports spare parts that are assembled in the peripheral country. It produces manufactures, which can be of relatively high technological content, nonetheless, the aggregate value added is very low as it only adds labor. There also exists a high productivity sector, mainly the automotive, which achieves its international competitivity because its productivity is at similar levels to those of the central countries in terms whilst wages are pulled downwards by the wage repression exerted upon the rest of the economy (Palma, 2005).

The Mexican economy is a platform that integrates labor to the last stage of the production process, that is disconnected from the rest of the productive structure as there is very little domestic production added. The connection is between the main companies and the subsidiaries, the production chains are transnational. Its competitivity level, then, depends on low labor costs (both direct wages and indirect social security costs), high flexibility of the labor market, low taxes and low environmental regulations. It is an economic mode that depends on profits and represses internal demand, generates low growth, low job creation, the incapacity to build productive chains that integrate more added value. Thus, productivity gains are in general low and there is no upgrading as the productive stage which is concentrated in Mexico is the one with the lowest productivity level.

This is the reason why, although Mexico has become one of the largest exporters of manufactures in the world, and the biggest in Latin America, the impact of this boom has been very limited internally. In fact, the maquiladoras proper, that still constitute around $60 \%$ of total exports, are exclusively assembling enterprises that incorporate a minimum part of national products (around 3\%). The State does not actively seek any sort of integration of the industry, as the Korean or Taiwanese did, or the transfer of technology, as the Chinese State does, and as the Mexican governments did during the ISI period. The Mexican State merely sets the "stage" for private investments. In fact, the Free Trade Agreement with the United States and Canada (NAFTA) imposes very significant restrictions for governmental action: it cannot subsidize through cost reduction or allocate loans with lower interests to any national economic sector, it cannot discriminate against foreign 
investment, nor limit the entry or exit of foreign capital, among others. These conditions greatly constraint the Mexican State, in comparison with the Brazilian or the Chinese. In addition, the ideology of the government officials since mid-eighties has been totally in accordance with these restrictions to State action and the opening of the economy.

A very significant characteristic of the economic model followed by Mexico is maintaining minimum requirements to foreign capital, in terms of salaries, social protection (low with respect to other countries in Latin America, although high with respect to China), and tax pressure, among others. The State does not stimulate internal market, on the contrary, it represses salaries and limits redistribution through social policies, concentrating its efforts on minimalist assistance programs like Oportunidades and the Seguro Popular, as a manner of enhancing its competitiveness which reposes on low labor costs and high flexibility. While some Latin American countries managed to reduce inequality to a considerable extent between 2002 and 2012 and reduce poverty, in Mexico it has stayed almost constant since the mid 90s (Fritz and Lavinas, 2015; Boyer, 2015). Although the Brazilian Gini index is still higher than the Mexican, making Brazil a more unequal country, nonetheless, inequality in Brazil was significantly reduced in the last decade; while the Brazilian Gini index was almost constant in the nineties, during the government of Cardoso, it was sharply reduced during the two Lula governments, since 2004: it went from 60 to 53 (Therborn, 2015). On the other hand, while poverty was significantly reduced in Brazil, in absolute terms it has even increased in Mexico. Finally, in Brazil the middle class has grown significantly, in Mexico it has barely moved.

As we have defended in this and other articles, an economic model is the result of a socio-economic compromise. Mexico's socio-economic arrangement is between the State, the multinational companies (national and foreign), the big national economic groups and the financial capital. Civil society (unions, social organizations) is weakly organized, and both the State and the political system are disconnected from it. As a result, the Mexican State has little autonomy with respect to the dominant groups, and the result is an oligopolistic economic structure, and an oligarchic political structure. This arrangement, favors the big national and transnational enterprises and a small middle class that has grown around these enterprises, but is disconnected from the rest of the economy, while it disfavors the enterprises and the population living from the internal market, and the informal workers and the poor.

This is possible in Mexico because the political regime in place is a partitocracy, where the political parties are disconnected from civil society. In contrast, in China we face an authoritarian regime which seems to have a clear strategic outlook and project, while in Brazil we have a democracy with a significant participation of civil society.

This political situation is partly due to a different periodization of democratization in both Latin American countries and the absence of democratization in the case of China. While in Brazil, democratization occurred before liberalization and 
resulted from an active civil society in the 70 s and 80 s, leading to a less orthodox liberalization and a more profound democracy, in the case of Mexico liberalization was impose before democratization (like in China), and was thus much more orthodox and led to the weakening of civil society, and thus of democracy. In fact, although labor was a main actor throughout the Mexican post-revolutionary history and a significant just before liberalization, it was effectively demobilized by the incumbent PRI governments, and democratization occurred mainly at the formal-electoral level. The new economic model the served to flexibilize the industrial relations system, weaken the unions and dismantle the welfare State (Bizberg, 2010).

\section{FINAL REMARKS}

Although, at present, the Chinese model seems to be more sustainable, due to its capacity to sustain high growth and upgrade its economy, it has significant weaknesses that may foreshadow future problems. While it has assured high growth rates and continuous productivity increases, it has also implied a retreat of the social security benefits that the Chinese population enjoyed under communism. Nowadays, access to health and education depends on private disbursements as local governments are incapable of providing these services. Both middle classes and low income sectors have to spend increasing amounts of resources to cover these services (Kharas, 2010, p. 31; Boyer, 2012, p. 196). Salaries have been kept low due to the continuous legal and illegal migration from the countryside to the cities, as many migrants that arrive in the cities do not have any rights and to the fact that Chinese workers are under official trade unions that are dependent on the directives of the communist party. Nonetheless, this process seems to be wearing out as salaries have begun to increase in the cities (Salama, 2012, p. 235). Finally, some regions have developed faster than others. This has increased inequalities that, according to some authors, may hinder further growth (Ozturk, 2016, p. 729).

This is the first of the imbalances of the Chinese model, mentioned by Boyer, and the main obstacle for China to transform itself from an export oriented economy to an internal market driven economy. Another of the imbalances is the non-performing loans that have resulted from the alliance between politicians and entrepreneurs. A third imbalance is linked to the overcapacities that have been generated by the immense infrastructure investments that the State has been obliged to sustain as a means to absorb the population that is migrating from the countryside (Boyer, 2012, p. 196).

These three difficulties of the Chinese economy delimit a growth pattern that is structurally oriented externaly. They, thus, pose a serious challenge to the declared intent of the government to orient its economy towards the internal market, a wage led growth. In fact, the model and the social pact (authoritarianism, controlled unions, migration control vs. economic growth) depends on an imbalance towards profits against wages: the wage led share in GDP has fallen and the household consumption in total demand has declined (Boyer, 2012, p. 196; Kharas, 
2010, p. 32). In order to reorient the economy internally, a shift from the use of the profits of the State and communal enterprises from overall physical investment (which as we have mentionned has already reached over-investment levels) to investment in human capital: health, education, social security, in order to leave more leeway to the families to spend on consumption (Kharas, 2010, p. 32).

According to Ozturk, Latin America is caught in the middle-income trap. While the low income countries have as their main advantage to grow profiting from the low salaries by way of labor intensive industries, and the high-income countries have a comparative advantage in capital and technology intensive industries, middle-income countries have no comparative advantage (Ozturk, 2016, p. 728). Middle-income countries need to upgrade, they require "[...] strategic, pro-active, and coherent government policies for capability advancement are the key factors [...] only the development of technological capabilities can ensure growth and broadbased upgrading. This requires moving from commodity production to knowledge intensive and innovative activities (Ozturk, 2016, p. 728).

While Brazil had a strategic and pro-active policy that tried to upgrade its industry and had some success in some sectors such as aeronautics, oil and biotechnology, it finally failed because it was incapable of controlling the effects of the commodities boom. The present Brazilian crisis is proof that the economic model it followed was not sustainable (economically and politically), although the political crisis deepened an economic crisis that may have been less profound, as it was being faced by the government of Dilma with orthodox and heterodox measures. Although the Mexican model is not passing through an open crisis, it is also unsustainable, as it is immersed in a rampant crisis of low growth, low job creation, low salaries, in sum in a low upgrading trap.

\section{REFERENCES}

Águila, Nicolás and Rubén Lo Vuolo. (2016) “Argentina y Brasil: los límites de los regímenes de crecimiento liderados por el empleo y los salarios", paper presented in the Symposium "Las diversidades del capitalismo en América Latina. Un estudio sobre la complementariedad entre las distintas conformaciones socio-políticas y las políticas económicas", $8^{\circ}$ Congress, Consejo Europeo de Investigaciones Sociales en América Latina, Instituto de Iberoamérica, University of Salamanca.

Aglietta, Michel and Guo Bai. (2012) La Voie Chinoise. Capitalisme et Empire, Paris: Odile Jacob.

Alesina, Alberto. (1994) "Political Models of Macroeconomic Policy and Fiscal Reforms", in S Haggard and S Webb (eds), Voting for Reform, Oxford, UK: Oxford University Press.

Asian Development Bank. (2010) The Rise of Asia's Middle Class, Key Indicators for Asia and the Pacific, Manila Phillipines: ADB. https://www.adb.org/publications/key-indicators-asia-and-pacific- 2010

Banerjee Abhijit and Esther Duflo. (2008) "What is middle class around the world? “, Journal of economic perspective $22(2)$, pp. 3-28

Birdsall, Nancy. (2010) "The (indispensable) middle class in developing countries; or, the rich and the rest, not the poor and the rest", Working paper 207, Centre for global Development.

Bizberg, Ilan. (2014) “Types of capitalism in Latin America”. Interventions économiques / Papers in Political Economy, no. 49, Université de Québec á Montréal,. 
Bizberg, Ilan. (2011) “The global economic crisis as disclosure of different types of capitalism”, Swiss Journal of Sociology, Vol. 37 Issue 2, pp. 321-339

Bizberg, Ilan (2010), "La democracia vacía”, in Ilan Bizberg and Francisco Zapata (ed.), Los Grandes Problemas de México. Los movimientos sociales, México, El Colegio de México.

Boyer, Robert. (n.d) "How the specificity of Chinese capitalism explain its position in the world economy", Voces en el Fenix, http://robertboyer.org/download/How\%20the\%20specificity\% 20 of $\% 20$ Chinese $\% 20$ capitalism $\% 20$ explains $\% 20$ its $\% 20$ position.pdf

Boyer, Robert. (2012) “The Chinese growth regime and the world economy”, in Robert Boyer, Hiroyasu Uemura and Akinori Isogai, Diversity and transformations of Asian Capitalisms, London and New York: Routledge, pp.184-208.

Boyer, Robert. (2014) "Is More Equality Possible in Latin America? A Challenge in a World of Contrasted but Interdependent Inequality Regimes”, desiguALdades.net Working Paper Series 67, Berlin: Freie Universität Berlin.

Bresser-Pereira, L. C. (2015), "Reflecting on new developmentalism and classical developmentalism". FGV São Paulo, Working Paper 395.

Bresser-Pereira, L. C. Y Paulo Gala (2012), “Macroeconomía estructuralista del desarrollo: ¿un segundo momento del estructuralismo latinoamericano?, en Jose Luis Calva (coord.), Análisis Estratégico para el Desarrollo, Vol. 4, México Juan Pablos Editor, pp. 245-272.

Chun, Natalie. (2010) "Middle Class Size in the Past, Present, and Future: A description of Trends in Asia”, Working Paper Series, no. 217, Manila Phillipines, Asian Development Bank.

Cardoso, Fernando Henrique and Enzo Faletto. (1969) Dependencia y Desarrollo en América latina, México: Siglo XXI, 1969.

Castellani, Francesca, Gwen Parent, Jannet Zentero. (2014) “The Latin American Middle Class. Fragile After All?”, Working Paper Series, No. 557, IDB.

Chen, Jie. (2013) A middle Class without Democracy: Economic Growth and the Prospects for Democratization in China, Oxford: Oxford University Press.

Neri, Marcelo. (2008) A nova classe média, Rio de Janeiro: Fundaçao Getulio Vargas, www.fgv/cps/ classe.media

Neri, Marcelo (2011), A Nova Classe Média. O lado brillante da base da pirâmide, Sao Paulo, Editora Saraiva.

Easterly, William. (2001), The Middle Class Consensus and Economic Development. Journal of Economic Growth. 6(4): 317-335.

Fritz, Barbara and Lena Lavinas. (2015), A Moment of Equality for Latin America? Challenges for Redistribution, Surrey and Burlington, Ashgate

Haggard, Stephan. (1990) Pathways from the Periphery. The Politics of Growth in the Newly Industrializing Countries. New York: Cornell University Press.

Kandogan, Yener and Scott D. Johnson (2016), "Role of economic and political freedom in the emergence of global middle class", International Business Review, 25: 711-725.

Kharas H. (2010): "The emerging middle class in developing countries ", Working paper, no. 285, OECD Development centre.

Lora Eduardo and Johanna Fajardo. (2011), "Latin American middle class : the distance between perception and reality”, IDB Working Paper Series, 275, IDB https:/publications.iadb.org/bitstream/ handle/11319/3818/Latin\%20American\%20Middle\%20Classes\%3a\%20The\%20Distance \%20 between $\% 20$ Perception $\% 20$ and $\% 20$ Reality.pdf?sequence $=1$

Milanovic Branko and Shlomo Yitzhaki. (2002), « Does decomposing world income distribution : does the world have a middle class ? ", Review of Income and Wealth, 48, 2: 155-178.

Ozturk, Ayse. (2016) "Examining the economic growth and the middle-income trap from the perspective of the middle class, International Business Review, 25: 726-738.

Palma, José Gabriel, “The Seven Main 'Stylized Facts' of the Mexican Economy Since Trade Liberalization and NAFTA", Industrial and Corporate Change, vol. 14, n 6, 2005.

Prates, Daniela, Barbara Fritz, Luiz Fernando de Paula. (2017) "Brazil at Crossroads: A Critical Assessment of Developmentalist Policies”, manuscript, Freie University of Berlin, 2017. 
Ravaillon Martin. (2009) “The developing world's bulging (but vulnerable) middle class”, Policy Research Working Paper, no. 4816, World Bank.

Rodrik, Dani. (2007) One economics, many recipes. Globalization, Institutions and Economic Growth, Princeton and Oxford: Princeton University Press.

Salama, Pierre. (2012) “China-Brasil: industrialización y ‘desindustrialización temprana’”, Cuadernos de Economía, 31(56).

Salama, Pierre. (2014) "Les classes moyennes peuvent-elles dynamiser la croissance du PIB dans les économies émergentes?", Working paper, no. 61, Paris: FMSH.

Scalon, Celi and Andrés Salata, (2012) "Uma Nova Classe Média no Brasil sa última década? O debate a partir da perspectiva sociologica”, Revista Sociedade e Estado, Vol. 27, no. 2.

Stampini, Marco, Marcos Robre, Mayra Sáenz, Pablo Ibarrarán, Nadin Medellín. (2015), "Pobreza, vulnerabilidad y la clase media en América Latina”, Working Paper, no. 591, IDB.

Therborn, Göran (2015), "Moments of Equality - Today's Latin America in a Global Historical Context”, in Fritz, Barbara and Lena Lavinas, A Moment of Equality for Latin America? Challenges for Redistribution, Surrey and Burlington, Ashgate. 